\title{
Removal of Cd(II) from Aqueous Solution by Clay- biochar Composite Prepared from Alternanthera philoxeroides and Bentonite
}

\author{
Yande Jing, ${ }^{\mathrm{a}, \mathrm{b}}$ Yongqiang Cao, ${ }^{\mathrm{a}, \mathrm{b}}$ Qianqian Yang, ${ }^{\mathrm{a}, \mathrm{b}}$ and Xuan Wang a,b \\ A novel bentonite-biochar (APB) composite was prepared by incorporating \\ bentonite (BE) with Alternanthera philoxeroides (AP) biochar for the \\ adsorptive removal of $\mathrm{Cd}(\mathrm{II})$ from aqueous media. The APB and the \\ pristine biochar (PB) prepared from the AP were produced at $300^{\circ} \mathrm{C}$ under \\ a nitrogen environment. The adsorption capabilities of the $\mathrm{BE}, \mathrm{PB}$, and \\ APB were tested for the removal of $\mathrm{Cd}(\mathrm{II})$ from aqueous solution. The \\ results showed that the $\mathrm{pH}$ substantially affected the adsorption of $\mathrm{Cd}(\mathrm{II})$ \\ by the PB and APB. The adsorptive capacity of the $\mathrm{Cd}(\mathrm{II})$ onto the PB and \\ APB gradually increased as the $\mathrm{pH}$ was increased to 6.0 , and there was \\ no significant change in adsorption as the $\mathrm{pH}$ was further increased to 8.0. \\ The adsorption kinetic data of the PB and APB were fitted to a pseudo- \\ second-order (PSO) adsorption kinetic model and an intraparticle diffusion \\ (ID) model. The Freundlich model matched the experimental data better \\ than the Langmuir model, indicating that the adsorption was \\ heterogeneous. Thermodynamic study revealed that the adsorption was \\ mainly physisorption, and the adsorption process was endothermic and \\ spontaneous, while the orderliness of all adsorption systems decreased. \\ The results demonstrated that the APB was an effective adsorbent for the \\ removal of $\mathrm{Cd}(\mathrm{II})$ from aqueous media.
}

Keywords: Clay-biochar; Cd(II); Aqueous solution; Removal

Contact information: a: College of Geography and Tourism, Qufu Normal University, 80 Yantai Road, Rizhao, Shandong, 276826, China; b: Key Laboratory of Nansi Lake Wetland Ecological and

Environmental Protection in Universities of Shandong, 57 Jingxuan Road, Jining, Shandong, 273165,

China; *Corresponding author: jingyande@163.com

\section{INTRODUCTION}

Cadmium(II) (Cd(II)) pollution has become a severe environmental problem around the world. More than 20,000 tons of $\mathrm{Cd}(\mathrm{II})$ enters the environment every year (Hayat et al. 2019). The concentration of Cd(II) in heavily polluted waters in China is as great as $4500 \mu \mathrm{g} / \mathrm{L}$, while the national safety standard for Cd(II) is $0.1 \mathrm{mg} / \mathrm{L}$ (GB 89781996). Cadmium(II) and its compounds are soluble in water and have high fat solubility, bioaccumulation, and toxicity. They can enter the food chain and ultimately endanger human life and health.

Biochar has a well-developed porous structure. It has good adsorption properties for the removal of heavy metal ions and organic pollutants in water and soil (Ahmad et al. 2014; Cao et al. 2019). Using biochar to treat heavy-metal-polluted water has attracted wide interest over the past few decades. Alternanthera philoxeroides (AP), also known as revolutionary grass, water peanut, or lotus, is an invasive and harmful weed in China's water and terrestrial ecosystem (Holm et al. 1977). It has strong resistance, wide adaptability, and rapid reproduction, and its invasion has caused profound harm to the 
environment ( $\mathrm{Li}$ and Liu 2002). Currently, harvested AP is often treated by natural decomposition, which causes secondary environmental problems by releasing pathogens and methane (Xiao et al. 2009). However, conversion of the AP into biochar for remediation of heavy-metal-contaminated wastewater can utilize this harmful weed as a resource and avoid secondary pollution, while also expanding the material types of biochar and yielding economic benefits. To the authors' knowledge, little research has been performed on using biochars from AP for the treatment of contaminated media. Only Huang et al. (2016) and Yang et al. (2014) have made preliminary explorations in this respect. Therefore, it will be of great ecological, environmental, and economic benefit to apply biochar prepared from AP to the remediation of heavy metals in wastewater.

At present, methods of removing Cd(II) from wastewater include extraction, membrane separation, ion exchange, and adsorption, among others (Gupta et al. 2009). The central pursuit of the adsorption method is seeking high-performance adsorbents. Recently, porous minerals (including zeolite, bentonite (BE), kaolin, and diatomite) have shown considerable advantages in the preparation of high-performance adsorbents (Wang et al. 2015a). Bentonite is a natural, layered, silicate clay mineral with a large specific surface area, excellent adsorption performance, and ion exchange capacity. It can be used for the remediation of heavy metal contamination with good results (Soetaredjo et al. 2017). However, BE tends to expand, disperse, and suspend in aqueous solution, and the effect of solid-liquid separation is poor, so it is limited in the treatment of wastewater (Luo et al. 2014). To improve the shortcomings of BE, some researchers have prepared a BE-based composite adsorbent and have used it to adsorb heavy metals in water (Fosso-Kankeu et al. 2017).

Clay-biochar composite adsorbents have been prepared in previous studies in attempts to increase the amount of pollutants that can be adsorbed compared to the pure adsorbents (Fosso-Kankeu et al. 2017). Bentonite-biochar composites have shown reasonably good results in previous studies (Laysandra et al. 2018). Previous research (Lee et al. 2013; Hao et al. 2017) has shown that the nature of the biomass remarkably affects the physicochemical composition of the biochar derived from it. Evidently, a replicate of the above composite with different biomass will exhibit different properties and affinities toward metals. To the authors' knowledge, no studies have examined the application of composite adsorbents from $\mathrm{AP}$ and $\mathrm{BE}$ for the remediation of $\mathrm{Cd}(\mathrm{II})$-contaminated wastewater. In this study, clay-biochar (APB) composites derived from the AP and BE were prepared at $300{ }^{\circ} \mathrm{C}$, and the obtained composite adsorbents were evaluated for their ability to remove $\mathrm{Cd}$ (II) from aqueous solution. Equilibrium and kinetic experiments of $\mathrm{Cd}(\mathrm{II})$ adsorption with BE, pristine biochar (PB), and APB were performed. Furthermore, Fourier-transform infrared spectroscopy (FTIR), X-ray diffraction (XRD), and scanning electron microscopy (SEM) were used to characterize the structural differences in the BE, $\mathrm{PB}$, and $\mathrm{APB}$. The effects of $\mathrm{pH}$ and temperature were studied. Finally, the mechanisms of $\mathrm{Cd}(\mathrm{II})$ removal by the $\mathrm{BE}, \mathrm{PB}$, and $\mathrm{APB}$ were explored and discussed.

\section{EXPERIMENTAL}

\section{Materials}

The AP was collected from a pond in Rizhao, Shandong, China (35 $35^{\circ} \mathrm{N}, 119^{\circ}$ $\left.16^{\prime} \mathrm{E}\right)$. The collected material was cleaned with tap water and then cleaned with deionized water approximately three times. It was placed in a clean and ventilated location for natural 
air drying, washed, and oven-dried at $80{ }^{\circ} \mathrm{C}$. Then, it was crushed by a grinder and sieved through a 100-mesh screen for subsequent experiments.

The calcium-based BE was purchased from Henan Yixiang Material Co., Ltd. (Henan, China). After simple physical purification, the calcium-based BE was screened using a $0.15-\mathrm{mm}$ sieve. Reagents were purchased from Tianjin Hengxing Chemical Reagent Co., Ltd. (Tianjin, China). All other chemicals used in these experiments were analytical grade. All solutions were prepared with deionized (DI) water.

\section{Clay-biochar composite preparation}

The APB composite was prepared by adapting the procedure used by Yao et al. (2014). First, $2 \mathrm{~g}$ of the BE powder was dissolved in $500 \mathrm{~mL}$ of DI water and treated by sonication (KQ-100V; Kunshan Ultrasonic Instruments Co., Ltd., Kunshan, Jiangsu, China) of the mixture for $30 \mathrm{~min}$ to stabilize the BE suspension. Then, $10 \mathrm{~g}$ of the AP was weighed, immersed in the BE suspension, and stirred for $2 \mathrm{~h}$. Finally, the feedstocks were separated from the mixture and oven-dried at $80{ }^{\circ} \mathrm{C}$.

The feedstocks were air-dried and ground, packed into a closed ceramic crucibles, and put into a preheated $\left(75^{\circ} \mathrm{C}\right)$ muffle furnace (KSY-12D-16, Longkou City Factory Furnace, Wuhan, China). The feedstocks were decomposed for $2 \mathrm{~h}$ at $300^{\circ} \mathrm{C}$ in oxygenlimited conditions with the inert atmosphere achieved with an $\mathrm{N}_{2}$ flow rate of $0.5 \mathrm{~L} / \mathrm{min}$. The heating rate was $15^{\circ} \mathrm{C} / \mathrm{min}$. After being cooled to room temperature, the solids were cleaned several times with DI water to remove surface impurities and were oven-dried at $80{ }^{\circ} \mathrm{C}$ (Wang et al. 2015b). The $\mathrm{PB}$, without $\mathrm{BE}$ modification, underwent the same pyrolysis process. The obtained adsorbents were ground through a $0.15-\mathrm{mm}$ sieve and stored for later use. The BE-modified biochar and the unmodified biochar were denoted "APB" and "PB," respectively.

\section{Methods}

\section{Adsorbent characterization}

The surface morphologies and pore structures of the adsorbents were determined using SEM (JSM-5600LV; JEOL Ltd., Tokyo, Japan) at 1000× magnification coupled with an energy dispersive spectroscopy (EDS) instrument (Oxford model 7582, ISIS, USA). Fourier-transform infrared spectroscopy (Tensor 27; Bruker, Karlsruhe, Germany) was used to analyze the surface functional groups of the adsorbents. The adsorbents were ground and mixed with $\mathrm{KBr}$ wafers $(0.5 \%)$. At a $4 \mathrm{~cm}^{-1}$ resolution, the spectra were obtained over the range of $500 \mathrm{~cm}^{-1}$ to $4000 \mathrm{~cm}^{-1}$ with 64 scans. A CHN elemental analyzer (Vario EL Cube; Elementar Analysensysteme GmbH, Langenselbold, Germany) was used to determine the elemental composition $(\mathrm{C}, \mathrm{H}, \mathrm{N}, \mathrm{S})$ of the adsorbents, and the $\mathrm{O}$ content was obtained by a mass balance of ash content and elemental contents.

The $\mathrm{pH}$ values of the adsorbents were determined as follows: First, $2.5 \mathrm{~g}$ of the adsorbent was weighed and added into $50 \mathrm{~mL}$ of deionized water. The adsorbent was heated in airtight conditions, boiled for $5 \mathrm{~min}$, and filtered, discarding $5 \mathrm{~mL}$ of primary filtrate. The $\mathrm{pH}$ of the residual liquid after cooling was measured using a $\mathrm{pH}$ meter.

The ash contents of the adsorbents were determined as follows: First, $1.0 \mathrm{~g}$ of the adsorbent was weighed and burned in a muffle furnace at $650{ }^{\circ} \mathrm{C}$ for 1 hour in aerobic conditions. The ash content was calculated according to the quality of the adsorbents before and after burning. 


\section{Adsorption experiments}

The adsorption behavior was modeled by three methods: the isotherm model, the kinetic model, and the thermodynamic model. Before applying these models, the adsorption capacity was first determined using Eq. 1,

$$
q_{\mathrm{t}}=\frac{\left(C_{0}-C_{\mathrm{t}}\right) V}{m}
$$

where $q_{\mathrm{t}}$ is the amount of $\mathrm{Cd}(\mathrm{II})$ adsorbed per unit mass of adsorbent $(\mathrm{mg} / \mathrm{g}), C_{0}$ is the initial concentration of $\mathrm{Cd}(\mathrm{II})$ in the solution $(\mathrm{mg} / \mathrm{L}), C_{\mathrm{t}}$ is the $\mathrm{Cd}(\mathrm{II})$ concentration $(\mathrm{mg} / \mathrm{L})$ at time $t$ (with the equilibrium concentration also denoted $C_{\mathrm{e}}$ ), $m$ is the mass of the adsorbent $(\mathrm{g})$, and $V$ is the solution volume (L).

In the kinetic experiment, the adsorbent dosage was maintained at $0.5 \mathrm{~g} / \mathrm{L}$ with a $\mathrm{Cd}(\mathrm{II})$ concentration of $30 \mathrm{mg} / \mathrm{L}$. The $\mathrm{pH}$ of the system was maintained in the range of 7.0 to 8.0. A shaking speed of $200 \mathrm{rpm}$ was maintained during the kinetic experiment. The residence time was varied $(5 \mathrm{~min}, 10 \mathrm{~min}, 20 \mathrm{~min}, 30 \mathrm{~min}, 40 \mathrm{~min}, 1 \mathrm{~h}, 1.5 \mathrm{~h}, 3 \mathrm{~h}, 6 \mathrm{~h}, 9 \mathrm{~h}$, $15 \mathrm{~h}$, and $24 \mathrm{~h}$ ). After each run, the $\mathrm{pH}$ values of the suspensions were measured. Then, the concentrations of $\mathrm{Cd}(\mathrm{II})$ in the suspensions were determined using an atomic absorption spectrophotometer (GFA-7000A; Shimadzu, Kyoto, Japan) after the suspensions were filtered through a $0.45-\mu \mathrm{m}$-filter membrane. Three replications were performed for each contact time. Kinetic modeling was performed using the Origin 9.1 software package (OriginLab, Northampton, MA, USA).

To investigate the adsorption processes of the BE, PB, and APB for $\mathrm{Cd}(\mathrm{II})$, different sorption kinetic models were applied to fit the experimental data. These were the pseudofirst-order (PFO) kinetic model (Eq. 2), the pseudo-second-order (PSO) kinetic model (Eq. 3), and the intraparticle diffusion (ID) model (Eq. 4) (Bazrafshan et al. 2015),

$$
\begin{aligned}
& q_{\mathrm{t}}=q_{\mathrm{e}}\left(1-e^{-k_{1} t}\right) \\
& t / q_{\mathrm{t}}=\left(1 / k_{2} q_{\mathrm{e}}^{2}\right)+t / q_{\mathrm{e}} \\
& q_{\mathrm{t}}=k_{\mathrm{p}} \sqrt{t}+c
\end{aligned}
$$

where $q_{\mathrm{e}}$ and $q_{\mathrm{t}}$ are the amounts of $\mathrm{Cd}(\mathrm{II})$ adsorbed onto the adsorbent at equilibrium and at time $t(\mathrm{mg} / \mathrm{g})$, respectively, $k_{1}\left(\mathrm{~min}^{-1}\right)$ and $k_{2}(\mathrm{~g} /(\mathrm{mg} \cdot \mathrm{min}))$ are the rate constants of the PFO and PSO adsorption models, respectively, $k_{\mathrm{p}}$ is the ID rate constant $\left(\mathrm{mg} /\left(\mathrm{g} \cdot \mathrm{min}^{1 / 2}\right)\right)$, and $c$ is the linear intercept.

Adsorption isotherms were determined for different Cd(II) concentrations ( $20 \mathrm{mg} / \mathrm{L}$, $30 \mathrm{mg} / \mathrm{L}, 40 \mathrm{mg} / \mathrm{L}, 50 \mathrm{mg} / \mathrm{L}, 60 \mathrm{mg} / \mathrm{L}, 80 \mathrm{mg} / \mathrm{L}$, and $100 \mathrm{mg} / \mathrm{L})$ with a defined $\mathrm{pH}(\mathrm{pH} 7$ to 8$)$, adsorbent dosage $(0.5 \mathrm{~g} / \mathrm{L})$, and residence time $(24 \mathrm{~h})$. Other experimental conditions remained similar to the edge and kinetic experiments. The $\mathrm{pH}$ values of the suspensions were measured, and the $\mathrm{Cd}(\mathrm{II})$ concentrations of the suspensions were analyzed, as described above. Isotherm data for the adsorption of $\mathrm{Cd}(\mathrm{II})$ onto the $\mathrm{BE}, \mathrm{PB}$, and $\mathrm{APB}$ were modeled using the Langmuir (Eq. 5) and Freundlich (Eq. 6) isotherm models,

$$
\begin{aligned}
& q_{\mathrm{e}}=\frac{q_{\mathrm{m}} K_{\mathrm{L}} C_{\mathrm{e}}}{1+K_{\mathrm{L}} C_{\mathrm{e}}} \\
& q_{\mathrm{e}}=K_{\mathrm{f}} C_{\mathrm{e}}^{n}
\end{aligned}
$$

where $K_{\mathrm{f}}(\mathrm{mg} / \mathrm{g}) \cdot(\mathrm{mg} / \mathrm{L})^{-\mathrm{n}}$ and $K_{\mathrm{L}}(\mathrm{L} / \mathrm{mg})$ are the Freundlich and Langmuir affinity parameters, respectively, $q_{\mathrm{e}}$ is the equilibrium adsorption capacity $(\mathrm{mg} / \mathrm{g}), C_{\mathrm{e}}$ is the equilibrium liquid phase concentration $(\mathrm{mg} / \mathrm{L}), q_{\mathrm{m}}$ is the maximum adsorption capacity in 
the Langmuir model $(\mathrm{mg} / \mathrm{g})$, and $n$ is a Freundlich constant related to adsorption.

To obtain a complete description of the adsorption of $\mathrm{Cd}(\mathrm{II})$ onto the $\mathrm{BE}, \mathrm{PB}$, and APB, several thermodynamic properties of the adsorption system were assessed. The thermodynamic feasibility of the adsorption of $\mathrm{Cd}(\mathrm{II})$ onto the $\mathrm{BE}, \mathrm{PB}$, and $\mathrm{APB}$ was assessed through the standard Gibbs free energy change $\left(\Delta G^{\circ}, \mathrm{kJ} / \mathrm{mol}\right)$, standard enthalpy change $\left(\Delta H^{\circ}, \mathrm{kJ} / \mathrm{mol}\right)$, and standard entropy change $\left(\Delta S^{\circ}, \mathrm{kJ} /(\mathrm{mol} \cdot \mathrm{K})\right)$. The standard Gibbs free energy change was determined by Eq. 7,

$$
\begin{aligned}
\Delta G & =-R T \ln K^{\circ} \\
K^{o} & =q_{e} / C_{e}
\end{aligned}
$$

where $K^{\mathrm{o}}$ is a thermodynamic distribution coefficient. The value of $K^{\mathrm{o}}$ was obtained from Eq. 8 (Khan and Singh 1987), as shown in Eq. 9. The relation between the thermodynamic distribution coefficient and $\Delta H^{\circ}$ and $\Delta S^{\circ}$ is given by Eq. 9 ,

$$
\ln K^{\mathrm{o}}=-\frac{\Delta G}{R T}=\frac{\Delta S^{o}}{R}-\frac{\Delta H^{o}}{R T}
$$

where $R$ is the gas constant $(8.314 \mathrm{~J} /(\mathrm{mol} \cdot \mathrm{K})), T$ is the absolute temperature $(\mathrm{K})$, and $K^{0}$ is the equilibrium constant $(\mathrm{m} / \mathrm{M})$. The values of $\Delta H^{\circ}$ and $\Delta S^{\circ}$ could be calculated from the slope and intercept of the linear plot of $\ln K^{\mathrm{o}}\left(K^{\mathrm{o}}=q_{\mathrm{e}} / C_{\mathrm{e}}\right) v s .1 / T$.

\section{pH-dependent Experiment}

The effects of $\mathrm{pH}$ changes on $\mathrm{Cd}(\mathrm{II})$ adsorption by the $\mathrm{BE}, \mathrm{PB}$, and $\mathrm{APB}$ were studied by adjusting the $\mathrm{pH}$ of $40 \mathrm{~mL}$ of $\mathrm{Cd}(\mathrm{II})$ solution $(30 \mathrm{mg} / \mathrm{L})$ with $0.1 \mathrm{M} \mathrm{HNO}_{3}$ or $\mathrm{NaOH}$ in the $\mathrm{pH}$ range of 2.0 to 8.0 . Then, $0.02 \mathrm{~g}$ of adsorbent was added into a $100-\mathrm{mL}$ centrifugal tube. The concentration of $\mathrm{Cd}$ (II) was determined using the atomic absorption spectrophotometer after $24 \mathrm{~h}$ by shaking the mixture at $200 \mathrm{rpm}$ at $25^{\circ} \mathrm{C}$. The adsorption capacity of $\mathrm{Cd}(\mathrm{II})$ onto the adsorbents at different $\mathrm{pH}$ levels was calculated as described above.

\section{RESULTS AND DISCUSSION}

\section{Characterization of the Adsorbents}

The basic properties of the adsorbents are listed in Table 1. The ash contents of the PB and APB were $14.3 \%$ and $19.9 \%$, respectively. The yields of the PB and APB were $50.4 \%$ and $56.0 \%$, respectively. The ash content and yield of the APB were greater than those of the PB. This result might have been because the APB had the BE particles attached to the surface of the $\mathrm{PB}$, thus increasing the content of mineral components, such as $\mathrm{Si}, \mathrm{Mg}$, and $\mathrm{Al}$ in the APB, which increased the content of the APB after pyrolysis (Xu et al. 2013). As shown by the elemental compositions of the PB and APB, the most abundant element in the PB and APB was $\mathrm{C}$, followed by $\mathrm{O}$. Such results are consistent with other work (Cao et al. 2019). The $\mathrm{H} / \mathrm{C}, \mathrm{O} / \mathrm{C}$, and $(\mathrm{O}+\mathrm{N}) / \mathrm{C}$ ratios are often used to characterize the aromaticity and carbonization degree of adsorbents and the number and polarity of surface oxygen-containing functional groups (Ren et al. 2018). As shown in Table 1, the aromaticity of and the number and polarity of oxygen-containing functional groups in the $\mathrm{PB}$ were greater than or equal to those of the APB at the same pyrolysis temperature.

The $\mathrm{pH}$ values of the $\mathrm{PB}$ and APB were all greater than 7, indicating weak alkalinity and mainly being because the PB and APB used AP as a raw material. Organic acids and 
phenolic substances were formed due to the decomposition of hemicellulose and cellulose in the AP, which resulted in the $\mathrm{pH}$ of adsorbents being near neutrality. Furthermore, the $\mathrm{pH}$ of the APB was slightly lower than that of PB. This result was consistent with prior research (Premarathna et al. 2019) and was due to the inhibition of the BE adhering to the surface of the AP.

Table 1. Yield, pH, Ash Content, Elemental Composition, and Atomic Ratios

\begin{tabular}{|c|c|c|c|c|c|c|c|c|c|c|c|}
\hline \multirow{2}{*}{ Sample } & \multirow{2}{*}{$\begin{array}{c}\text { Yield } \\
(\%)\end{array}$} & $\mathrm{pH}$ & $\begin{array}{c}\text { Ash } \\
(\%)\end{array}$ & \multicolumn{3}{|c|}{ Elemental Composition (\%) } & \multicolumn{3}{|c|}{ Atomic Ratio } \\
\cline { 5 - 12 } & & & $\mathrm{N}$ & $\mathrm{C}$ & $\mathrm{H}$ & $\mathrm{S}$ & $\mathrm{O}$ & $\mathrm{O} / \mathrm{C}$ & $\mathrm{H} / \mathrm{C}$ & $\begin{array}{c}(\mathrm{O}+\mathrm{N}) / \\
\mathrm{C}\end{array}$ \\
\hline $\mathrm{PB}$ & $\begin{array}{c}50.45 \\
\pm 0.67\end{array}$ & $\begin{array}{c}7.35 \pm \\
0.05\end{array}$ & $\begin{array}{c}14.31 \\
\pm 0.43\end{array}$ & 2.68 & 47.70 & 4.19 & 0.24 & 30.88 & 0.65 & 0.09 & 0.70 \\
\hline $\mathrm{APB}$ & $\begin{array}{c}55.97 \\
\pm 0.12\end{array}$ & $\begin{array}{c}7.30 \pm \\
0.15\end{array}$ & $\begin{array}{c}19.91 \\
\pm 0.35\end{array}$ & 0.77 & 50.23 & 4.451 & 2.73 & 21.91 & 0.44 & 0.09 & 0.45 \\
\hline BE & - & $\begin{array}{c}8.75 \pm \\
0.02\end{array}$ & - & - & - & - & - & - & - & - & - \\
\hline
\end{tabular}

The SEM images and EDS (energy-dispersive X-ray spectroscopy) analysis of the adsorbents are shown in Fig. 1.
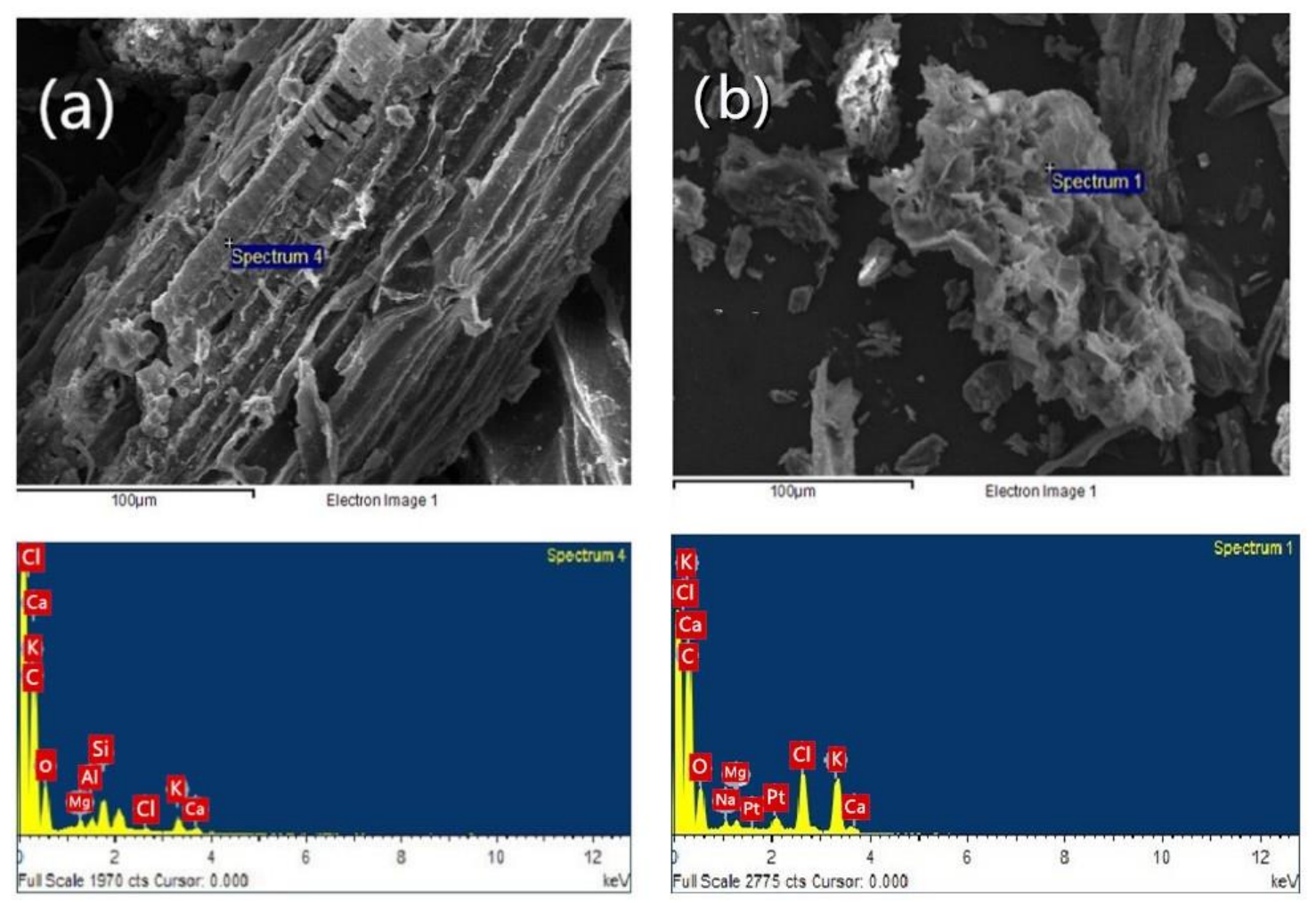

Fig. 1. SEM images and EDS spectra of (a) APB and (b) PB

The SEM results showed that the surface morphologies of the adsorbents varied remarkably between the different types. The PB had a completely tubular or sheet structure with a distinct pore or groove structure on its surface (Wang et al. 2019). The surface 
morphology of the APB was roughly tubular or of an irregular lamellar structure. The coverage of the BE particles on the surface of the AP biochar was evidenced by the EDS analysis. The BE particles could provide more adsorption sites for the APB. As shown in Fig. 1, compared with the PB, the EDS spectrum of the APB surface showed that the peak values of $\mathrm{Si}, \mathrm{Ca}, \mathrm{Mg}$, and $\mathrm{Al}$ were relatively high, all of which are typical of the elemental composition of montmorillonite, the main component of the BE. This result also shows that the BE was successfully loaded onto the AP biochar.

Fourier-transform infrared spectroscopy was used to qualitatively determinate the functional groups of the BE, PB, and APB. Figure 2 shows the FTIR spectra of the adsorbents. As shown, the types and richness of oxygen-containing functional groups differed greatly among the adsorbents. The stretching vibration absorption peaks of Si-O$\mathrm{Si}$ and Si-O existing in the APB composites were similar to those of the BE, which further indicated that the BE had been loaded onto the surface of the AP biochar.

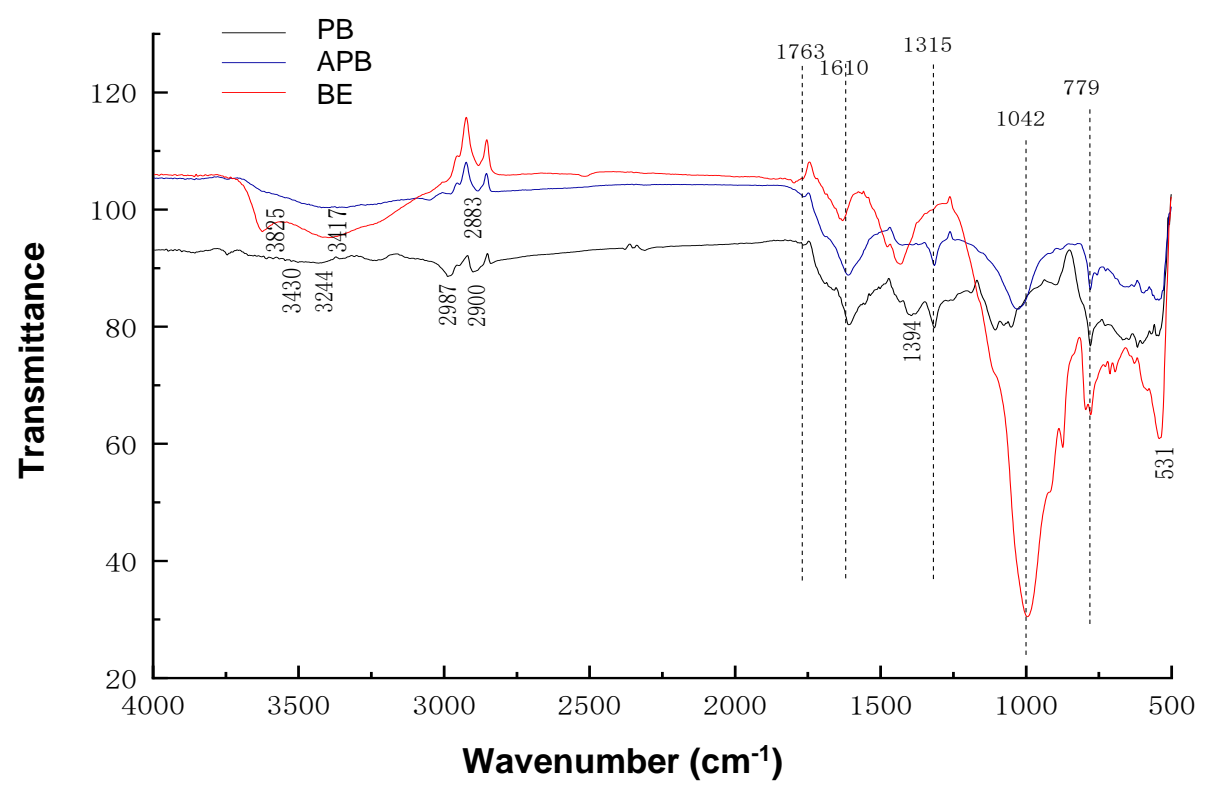

Fig. 2. FTIR spectra of the $P B, A P B$, and $B E$

The BE exhibited stretching vibration absorption peaks of hydroxyl (-OH) and hydrogen bonds $(-\mathrm{OH})$ at $3625 \mathrm{~cm}^{-1}$ and $3417 \mathrm{~cm}^{-1}$, respectively (Paluszkiewicz et al. 2008). The absorption peak near $2881 \mathrm{~cm}^{-1}$ was caused by the absorption vibration of - $\mathrm{CH}$. The stretching vibration at $1763 \mathrm{~cm}^{-1}$ was $\mathrm{C}=\mathrm{O}$, and the absorption peaks near $1628 \mathrm{~cm}^{-1}$ and $1426 \mathrm{~cm}^{-1}$ were $-\mathrm{NH}$ bending vibrations. The absorption peaks at $1042 \mathrm{~cm}^{-1}$ and 531 $\mathrm{cm}^{-1}$ were caused by Si-O stretching vibration and Si-O-Al deformation vibration, respectively, while the absorption peak at $775 \mathrm{~cm}^{-1}$ was caused by $\mathrm{Si}-\mathrm{O}-\mathrm{Si}$ stretching vibration (Alabarse et al. 2011).

The broad absorption peaks of the PB near $3430 \mathrm{~cm}^{-1}$ and $3244 \mathrm{~cm}^{-1}$ were caused by the stretching vibrations of phenolic hydroxyls (-OH) (Yu et al. 2018; Khan et al. 2010). Many absorption peaks near $2839 \mathrm{~cm}^{-1}$ to $2987 \mathrm{~cm}^{-1}$ were produced by the stretching vibration of aliphatic $-\mathrm{CH}_{2}$ (Zhang et al. 2011). The C-O absorption peak of carboxyl groups was at $1394 \mathrm{~cm}^{-1}$, the $\mathrm{C}=\mathrm{C}$ stretching vibration peak of aromatic rings was at 1610 
$\mathrm{cm}^{-1}$ (Zhao et al. 2013), and the C-O-C stretching vibration peak of ether in cellulose, hemicellulose, or lignin was at $1047 \mathrm{~cm}^{-1}$ (Premarathna et al. 2019). The bending vibration absorption peaks of aromatic $\mathrm{C}-\mathrm{H}$ were mainly located in the wavenumber band from 500 $\mathrm{cm}^{-1}$ to $779 \mathrm{~cm}^{-1}$. The absorption peaks near $1610 \mathrm{~cm}^{-1}, 1394 \mathrm{~cm}^{-1}$, and $1047 \mathrm{~cm}^{-1}$ decreased, which indicated that the number of carboxyl, ketone, and ether functional groups was relatively small.

The APB had a stretching vibration absorption peak of $-\mathrm{CH}$ near $2883 \mathrm{~cm}^{-1}$, which was similar to that of the PB near this band, indicating that all adsorbents had aliphatic functional groups. The peaks near $1763 \mathrm{~cm}^{-1}$ and $1610 \mathrm{~cm}^{-1}$ corresponded to the peaks of the $\mathrm{PB}$, which were the stretching vibration of $\mathrm{C}=\mathrm{O}$ and the stretching vibration of $\mathrm{C}=\mathrm{C}$ on aromatic rings. Near $1315 \mathrm{~cm}^{-1}$ was the stretching vibration peak of $\mathrm{C}-\mathrm{O}$, and near 1029 $\mathrm{cm}^{-1}$ was the Si-O-Si stretching vibration absorption peak (Ünlü et al. 2012). At $780 \mathrm{~cm}^{-1}$, the Si-O-Si stretching vibration absorption peak was similar to that of the BE. These characteristics indicated that the BE had successfully adhered to the surface of the AP biochar.

\section{pH Edge Experiments}

The $\mathrm{pH}$ of a solution is a major factor that controls adsorption onto adsorbents ( $\mathrm{Li}$ et al. 2017; Premarathna et al. 2019). The solution $\mathrm{pH}$ affects not only the surface charge of the adsorbents but also the forms and ionization degrees of heavy metals in solution, along with the adsorption rate and degree (Chang et al. 2016). When the $\mathrm{pH}$ is less than $8.0, \mathrm{Cd}(\mathrm{II})$ mainly exists in the form of free $\mathrm{Cd}(\mathrm{II})$ and a small amount of $\mathrm{Cd}(\mathrm{OH})^{+}$ions in the solution. Greater $\mathrm{pH}$ of the solution $(\mathrm{pH} \geqslant 8)$ will cause the precipitation of $\mathrm{Cd}(\mathrm{II})$ and interfere with the actual adsorption of $\mathrm{Cd}(\mathrm{II})$ onto the adsorbents (Chen et al. 2011). Therefore, this study examined solution $\mathrm{pH}$ in the range of 2 to 8 to test the adsorption of $\mathrm{Cd}(\mathrm{II})$ onto the adsorbents. As shown in Fig. 3, the initial $\mathrm{pH}$ of the solution had a substantial influence on the adsorption of the $\mathrm{Cd}(\mathrm{II})$.

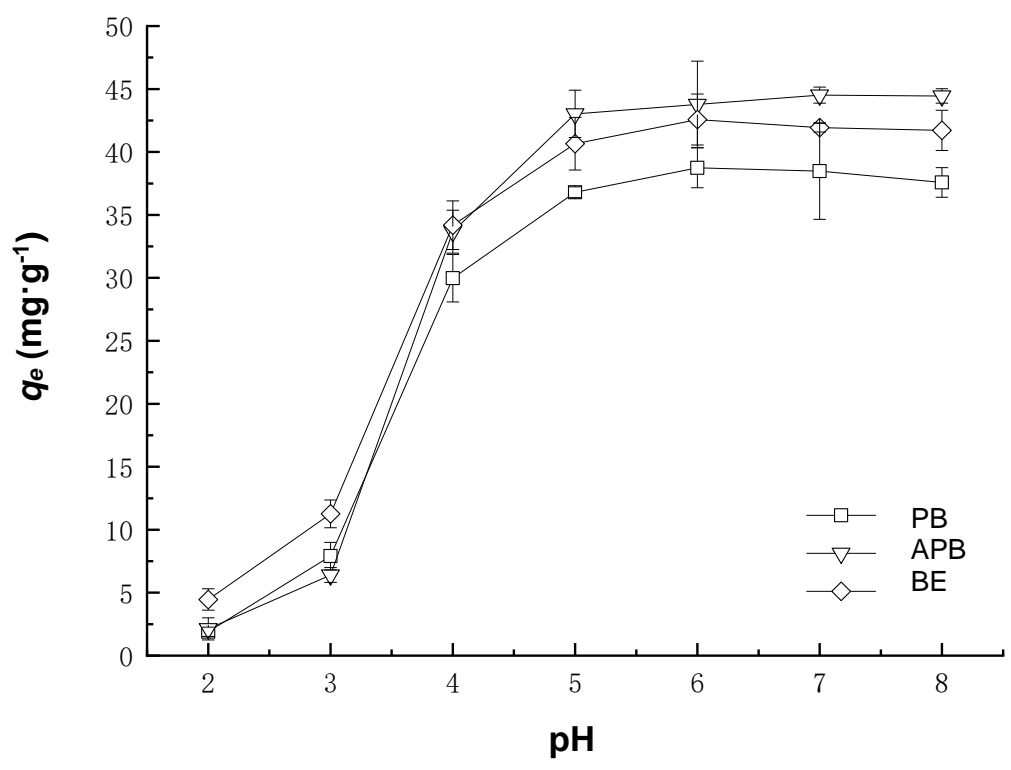

Fig. 3. Effects of initial solution $\mathrm{pH}$ on $\mathrm{Cd}(\mathrm{II})$ adsorption (Data are the mean \pm standard deviation based on duplicate measurements). 
Overall, the adsorbed amount of Cd(II) increased rapidly at first and then plateaued with increasing $\mathrm{pH}$. The greatest $\mathrm{Cd}$ (II) adsorption by the PB $(37.61 \mathrm{mg} / \mathrm{g})$ and APB $(44.3$ $\mathrm{mg} / \mathrm{g}$ ) was observed at a $\mathrm{pH}$ of 6.0. Compared to the PB and APB, the BE showed a similar trend in adsorption capacities in the $\mathrm{pH}$ range of 2.0 to 8.0 , and the maximum adsorption capacity was similarly obtained at a $\mathrm{pH}$ of 6.0. There are three possible reasons for the decreased $\mathrm{Cd}(\mathrm{II})$ adsorption capacities at low $\mathrm{pH}$ values. First, a large number of $\mathrm{H}^{+}$ions and $\mathrm{Cd}(\mathrm{II})$ in the solution competed for limited binding sites, which reduced the adsorption of Cd(II). Second, the increased solubility of crystal minerals in the adsorbents resulted in the release of many cations, such as $\mathrm{K}^{+}, \mathrm{Ca}^{2+}, \mathrm{Mg}^{2+}$, which competed with $\mathrm{Cd}$ (II) in the solution for limited adsorption points. Third, anions, such as $\mathrm{CO}_{3}{ }^{2-}$ and $\mathrm{PO}_{4}{ }^{3-}$, were difficult to precipitate with $\mathrm{Cd}$ (II) in solution. As the solution $\mathrm{pH}$ increased, the amount of $\mathrm{H}^{+}$in the solution decreased, and the cations (such as $\mathrm{K}^{+}, \mathrm{Ca}^{2+}$, and $\mathrm{Mg}^{2+}$ ) released by the adsorbent material also decreased, which reduced the competitive adsorption with $\mathrm{Cd}(\mathrm{II})$. Moreover, $\mathrm{Cd}(\mathrm{II})$ could easily precipitate with anions such as $\mathrm{CO}_{3}{ }^{2-}$ and $\mathrm{PO}_{4}{ }^{3-}$; thus, the adsorption capacity of $\mathrm{Cd}(\mathrm{II})$ onto the adsorbents increased. Moreover, the negative charge density on the surfaces of the adsorbents increased with the increased $\mathrm{pH}$, which was conducive to weakening the electrostatic repulsion of $\mathrm{Cd}(\mathrm{II})$ and thus increasing the adsorption capacity (Rivera-Utrilla et al. 2013).

\section{Kinetic Experiments}

Figure 4 shows the adsorption kinetics curve and models of the $\mathrm{Cd}(\mathrm{II})$ adsorption.
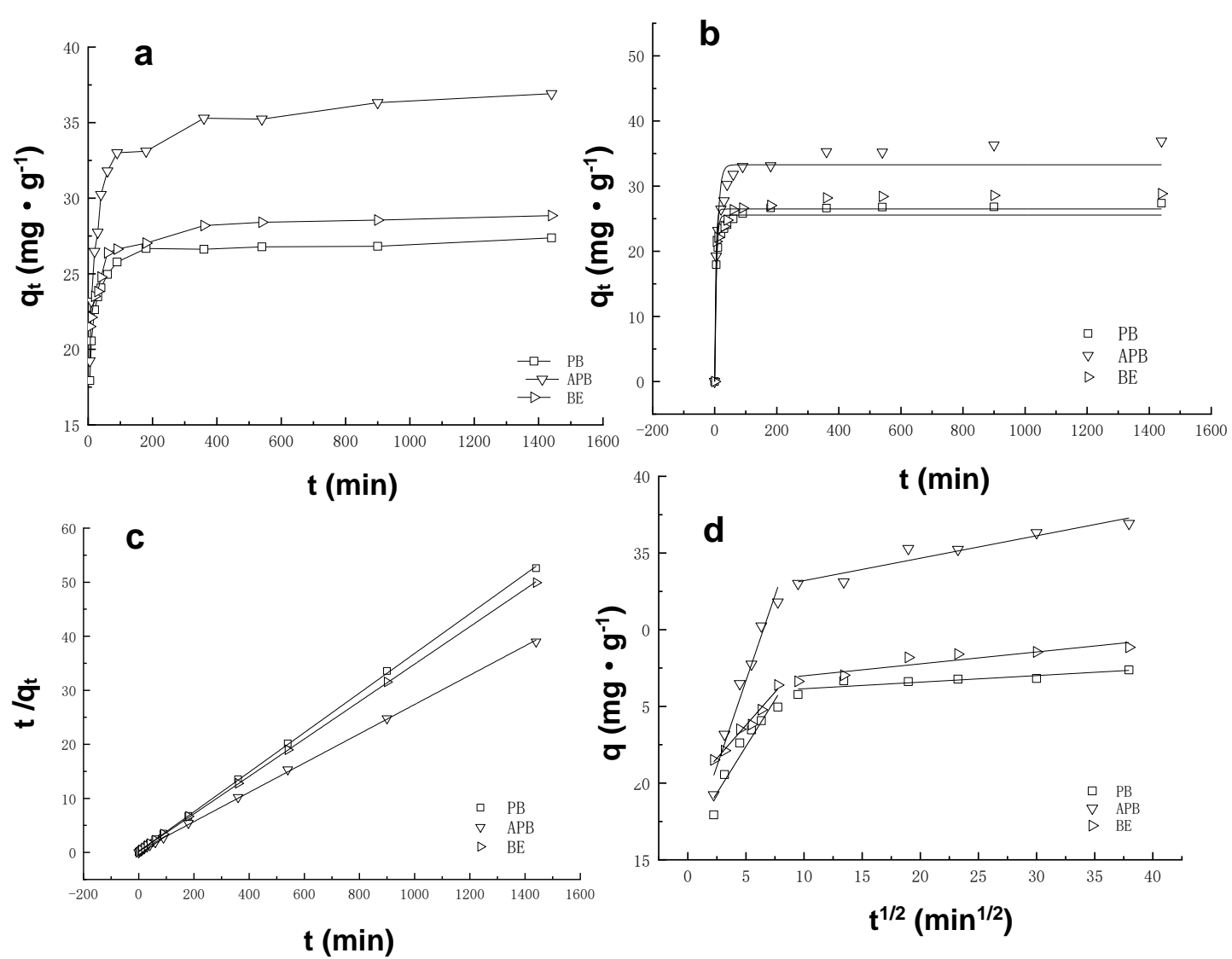

Fig. 4. Kinetic curve and fitted curves of Cd(II) adsorption: (a) kinetics curve, (b) PFO model, (c) PSO model, and (d) ID model 
The adsorption process could be divided into two distinct stages. The adsorption capacity of $\mathrm{Cd}$ (II) onto the adsorbents increased rapidly with increasing time in the early stage and then plateaued. At $360 \mathrm{~min}$, the adsorption capacities of the BE, PB, and APB to $\mathrm{Cd}(\mathrm{II})$ in solution reached $28.2 \mathrm{mg} / \mathrm{g}, 26.6 \mathrm{mg} / \mathrm{g}$, and $35.3 \mathrm{mg} / \mathrm{g}$, respectively, accounting for more than $95 \%$ of the adsorption capacity at $1440 \mathrm{~min}$, basically reaching the equilibrium state of adsorption. The decrease of the active adsorption sites on the adsorbent surfaces caused the decrease of the adsorption rate as time progressed, which caused the adsorption of $\mathrm{Cd}(\mathrm{II})$ to diffuse into the adsorbent material.

To better explore the adsorption process and mechanism of $\mathrm{Cd}(\mathrm{II})$ and the different adsorbents, based on the analysis of the adsorption kinetics curve, the experimental data were fitted by a PFO kinetic model (Fig. 4b) and a PSO kinetic model (Fig. 4c). The parameters of the PFO and PSO models obtained from the fitting of the experimental data are summarized in Table 2. Both of these models could represent the adsorption kinetic data well, according to the squared correlation coefficients $\left(\mathrm{R}^{2}>0.90\right)$. The $\mathrm{R}^{2}$ values of the PSO kinetic model were all greater than those of the PFO kinetic model. The theoretical equilibrium adsorption capacities ( $q_{\mathrm{e}}$, cal $)$ of the PSO kinetic model were $27.3 \mathrm{mg} / \mathrm{g}(\mathrm{PB})$, $36.9 \mathrm{mg} / \mathrm{g}$ (APB), and $28.9 \mathrm{mg} / \mathrm{g}(\mathrm{BE})$, which were close to the actual equilibrium adsorption quantities ( $q_{\mathrm{e}}$ exp) of $27.4 \mathrm{mg} / \mathrm{g}(\mathrm{PB}), 36.9 \mathrm{mg} / \mathrm{g}$ (APB), and $28.8 \mathrm{mg} / \mathrm{g}(\mathrm{BE})$. The PSO model had smaller deviations than the PFO model, which indicated that the PSO kinetic model could better describe the Cd(II) sorption kinetics. It has been shown recently that good fits to the PSO model are generally consistent with diffusion as the rate-limiting process (Hubbe et al. 2019).

The parameters $k_{1}$ and $k_{2}$ reflect the time required for the adsorption process to reach equilibrium in the PFO and PSO kinetic models, respectively (Plazinski et al. 2009). These parameters strongly depended on the applied operating conditions, such as temperature, initial concentration, solution $\mathrm{pH}$, and agitation rate. The adsorption rate constant $k_{2}$ was greater for PB (0.0072) than for APB (0.0026), and the time required for the $\mathrm{PB}$ to reach equilibrium was less than that for the APB. A possible reason was that it took more time and process for $\mathrm{Cd}(\mathrm{II})$ to adsorb on the $\mathrm{APB}$ due to the BE loading on the surface of the APB.

Table 2. Kinetic Parameters Obtained from PFO and PSO Kinetic Models of $\mathrm{Cd}(\mathrm{II})$ Adsorption onto the PB, APB, and BE

\begin{tabular}{|c|c|c|c|c|c|c|c|}
\hline \multirow[b]{2}{*}{ Sample } & \multirow[b]{2}{*}{$\begin{array}{c}q_{\mathrm{e}, \exp } \\
(\mathrm{mg} / \mathrm{g})\end{array}$} & \multicolumn{3}{|c|}{ PFO Kinetic Model } & \multicolumn{3}{|c|}{ PSO Kinetic Model } \\
\hline & & $\begin{array}{c}q_{\mathrm{e}, \mathrm{cal}} \\
(\mathrm{mg} / \mathrm{g})\end{array}$ & $k_{1}\left(\min ^{-1}\right)$ & $\mathrm{R}^{2}$ & $\begin{array}{c}q_{\mathrm{e}, \mathrm{cal}} \\
(\mathrm{mg} / \mathrm{g})\end{array}$ & $\begin{array}{c}k_{2} \\
(\mathrm{~g} /(\mathrm{mg} \cdot \mathrm{h}))\end{array}$ & $\mathrm{R}^{2}$ \\
\hline APB & 36.92 & $\begin{array}{c}33.29 \pm \\
0.99\end{array}$ & $\begin{array}{c}0.12 \pm \\
0.02\end{array}$ & 0.9155 & $\begin{array}{c}36.90 \pm \\
0.71\end{array}$ & $\begin{array}{c}0.0026 \pm \\
0.0003\end{array}$ & 0.9997 \\
\hline PB & 27.38 & $\begin{array}{c}25.55 \pm \\
0.50\end{array}$ & $\begin{array}{c}0.20 \pm \\
0.03\end{array}$ & 0.9543 & $\begin{array}{c}27.29 \pm \\
0.81\end{array}$ & $\begin{array}{c}0.0072 \pm \\
0.0011\end{array}$ & 0.9999 \\
\hline $\mathrm{BE}$ & 28.85 & $\begin{array}{c}26.48 \pm \\
0.64\end{array}$ & $\begin{array}{c}0.28 \pm \\
0.06\end{array}$ & 0.9287 & $\begin{array}{c}28.86 \pm \\
0.11\end{array}$ & $\begin{array}{c}0.0060 \pm \\
0.0001\end{array}$ & 0.9999 \\
\hline
\end{tabular}

To determine the actual rate-controlling steps of $\mathrm{Cd}(\mathrm{II})$ onto the $\mathrm{PB}$ and $\mathrm{APB}$, the ID model was used to fit the experimental data, and the curve in Fig. $4 \mathrm{~d}$ and the parameters in Table 3 were obtained. The whole adsorption process could be divided into two stages: The first stage ( 0 min to $60 \mathrm{~min}$ ) was the process of Cd(II) diffusion onto the surface of the $\mathrm{PB}$ and $\mathrm{APB}$, and $k_{\mathrm{p} 1}$ was greater than $k_{\mathrm{p} 2}$, indicating that the boundary diffusion process was fast, and the external surface adsorption was dominant. In the second stage (70 min to 
$1440 \mathrm{~min}$ ), the fitting curve plateaued, and $k_{\mathrm{p} 2}$ was less than $k_{\mathrm{p} 1}$, indicating that the adsorption of $\mathrm{Cd}$ (II) onto the $\mathrm{PB}$ and $\mathrm{APB}$ was a rate-controlling step in this stage. As shown in Table 3, the diffusion rate constant $k_{\mathrm{p} 1}$ was greater than $k_{\mathrm{p} 2}$. This result was mainly due to the decrease of $\mathrm{Cd}$ (II) concentration in the solution, which led to the decrease of the second stage diffusion rate and the final equilibrium state of Cd(II) adsorption. Meanwhile, the adsorption capacity on the external surface of the adsorbents tended to be saturated in the second stage. With the increase toward the adsorption capacity of the inner surface, the diffusion resistance of $\mathrm{Cd}(\mathrm{II})$ increased gradually, which led to a decrease in the diffusion rate. The $C$ value in Table 3 indicated the thickness of the adsorbent boundary layer. The $C$ value decreased with the increase of heterogeneity and hydrophilic groups on the surfaces of the adsorbents. As shown, $C_{1}$ was less than $C_{2}$, indicating that the adsorption effect of $\mathrm{Cd}(\mathrm{II})$ onto the adsorbents' boundary layers was much greater in the second stage than in the first stage. Figure $4 d$ shows that the adsorption process of the PB and APB for Cd(II) corresponded to multistage linear fitting. None of the straight lines passed through the origin but with positive intercept, indicating that the adsorption process was complicated and had a specific internal diffusion, which might be one of speed-controlling steps. There might be other unknown speed-controlling steps (Ma et al. 2011). The actual sorption process included surface adsorption and liquid membrane diffusion, which jointly controlled the adsorption reaction rate (Kara and Tuncel 2011).

Table 3. Parameters of the ID Model for Cd(II) Adsorption

\begin{tabular}{|c|c|c|c|c|c|c|}
\hline \multirow{2}{*}{ Sample } & \multicolumn{6}{|c|}{ ID Model } \\
\cline { 2 - 7 } & $\begin{array}{c}k_{\mathrm{p} 1} \\
\left(\mathrm{mg} /\left(\mathrm{g} \cdot \mathrm{min}^{1 / 2}\right)\right)\end{array}$ & $C_{1}$ & $\mathrm{R}^{2}$ & $\begin{array}{c}k_{\mathrm{p} 2} \\
\left(\mathrm{mg} /\left(\mathrm{g} \cdot \mathrm{min}^{1 / 2}\right)\right)\end{array}$ & $C_{2}$ & $\mathrm{R}^{2}$ \\
\hline APB & $2.23 \pm 0.23$ & $\begin{array}{c}15.53 \pm \\
1.19\end{array}$ & 0.9498 & $0.19 \pm 0.02$ & $\begin{array}{c}30.50 \pm \\
0.55\end{array}$ & 0.8905 \\
\hline PB & $1.22 \pm 0.19$ & $\begin{array}{c}16.29 \pm \\
0.99\end{array}$ & 0.8899 & $0.04 \pm 0.01$ & $\begin{array}{c}25.73 \pm \\
0.28\end{array}$ & 0.7113 \\
\hline BE & $0.86 \pm 0.06$ & $\begin{array}{c}19.46 \pm \\
0.29\end{array}$ & 0.9786 & $0.08 \pm 0.02$ & $\begin{array}{c}26.22 \pm \\
0.41\end{array}$ & 0.7964 \\
\hline
\end{tabular}

\section{Isotherm Experiments}

The isothermal adsorption experiments of $\mathrm{Cd}(\mathrm{II})$ onto the adsorbents in solution were performed at $288 \mathrm{~K}, 298 \mathrm{~K}$, and $308 \mathrm{~K}$. Figure 5 depicts the experimental data fitted by the Freundlich and Langmuir isothermal adsorption models. In Fig. 5, the adsorption experimental data are indicated with symbols, while the solid lines represent the theoretical data from the models. The temperature-dependent parameters obtained from the fitting of the experimental data are summarized in Table 4.

Figure 5 shows that with increasing equilibrium concentration of $\mathrm{Cd}(\mathrm{II})\left(C_{\mathrm{e}}\right)$, the equilibrium adsorption capacity $\left(q_{\mathrm{e}}\right)$ gradually increased, and the growth rate decreased. Furthermore, the actual adsorption capacity of the BE, PB, and APB increased with increasing temperature, which indicated that high temperature was beneficial to the adsorption of $\mathrm{Cd}(\mathrm{II})$ onto the $\mathrm{BE}, \mathrm{PB}$, and $\mathrm{APB}$, and the adsorption was spontaneous.

Table 4 shows that Freundlich isothermal adsorption model $\left(\mathrm{R}^{2}=0.9360\right.$ to 0.9932$)$ and the Langmuir isothermal adsorption model $\left(\mathrm{R}^{2}=0.8202\right.$ to 0.9650$)$ fitted the experimental data of $\mathrm{Cd}(\mathrm{II})$ adsorption onto the $\mathrm{BE}, \mathrm{PB}$, and APB well. Specifically, the fitting coefficients of the Freundlich model $\left(\mathrm{R}^{2}=0.9360\right.$ to 0.9932$)$ were greater than those of Langmuir model $\left(\mathrm{R}^{2}=0.8202\right.$ to 0.9650$)$, which indicated that the Freundlich model could better describe the adsorptive behavior of the $\mathrm{Cd}(\mathrm{II})$ onto the adsorbents. 


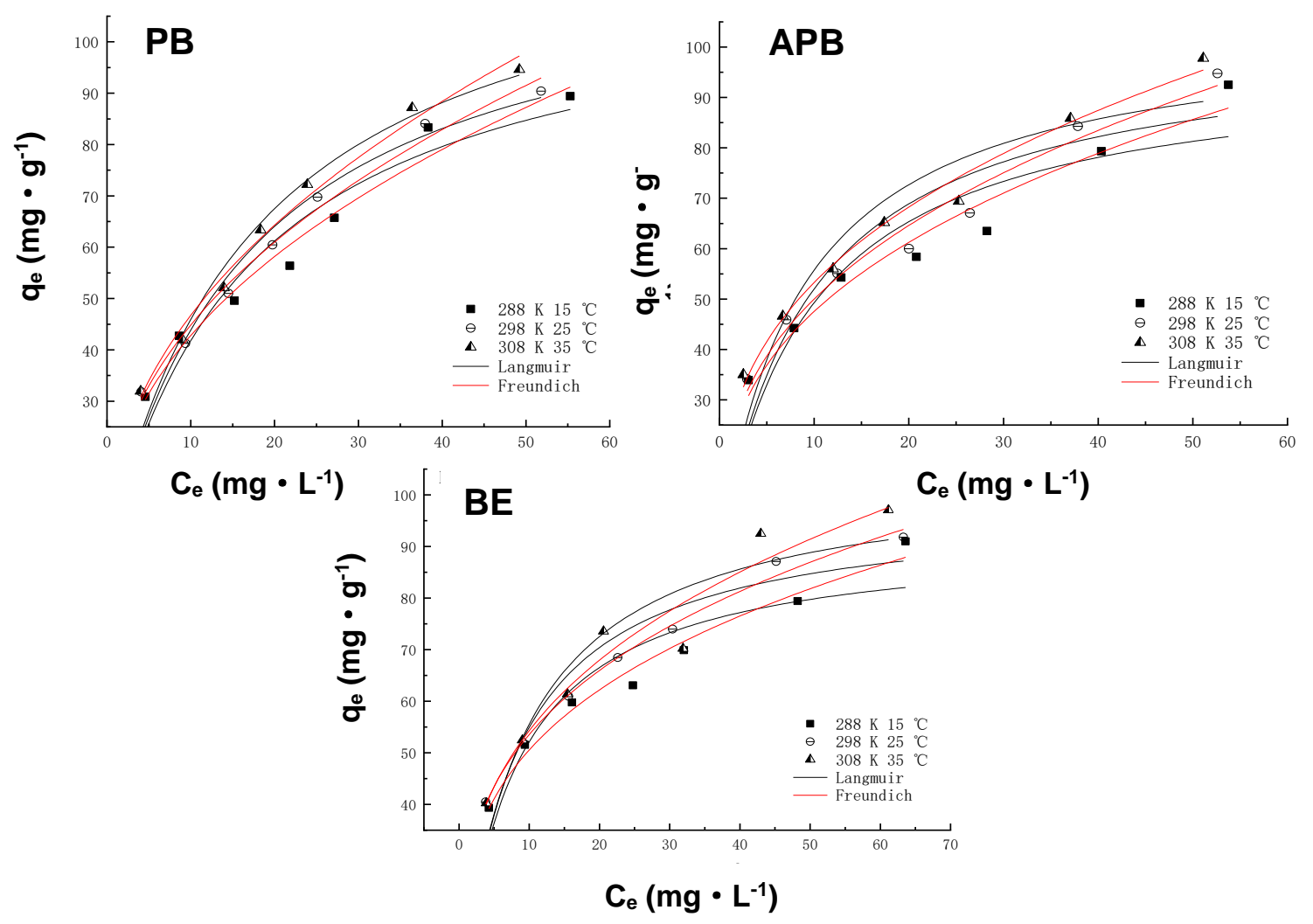

Fig. 5. Adsorption isotherms of $\mathrm{Cd}(\mathrm{II})$ at different temperatures

Table 4. Parameters of the Isothermal Sorption Models for Cd(II) Adsorption

\begin{tabular}{|c|c|c|c|c|c|c|c|}
\hline \multirow[b]{2}{*}{ Sample } & \multirow[b]{2}{*}{$\begin{array}{l}\text { Temperature } \\
(\mathrm{K})\end{array}$} & \multicolumn{3}{|c|}{ Freundlich Model } & \multicolumn{3}{|c|}{ Langmuir Model } \\
\hline & & $\begin{array}{c}K_{F} \\
(\mathrm{mg} / \mathrm{g}) \cdot(\mathrm{m} \\
\mathrm{g} / \mathrm{L})^{-n}\end{array}$ & $n$ & $\mathrm{R}^{2}$ & $q_{m}(\mathrm{mg} / \mathrm{g})$ & $K_{\mathrm{L}}(\mathrm{L} / \mathrm{mg})$ & $\mathrm{R}^{2}$ \\
\hline \multirow{3}{*}{ PB } & 288 & $\begin{array}{c}15.46 \pm \\
1.84\end{array}$ & $\begin{array}{c}0.4423 \pm \\
0.0346\end{array}$ & 0.9713 & $\begin{array}{c}93.89 \pm \\
1.52\end{array}$ & $\begin{array}{c}0.0581 \pm \\
0.0161\end{array}$ & 0.9566 \\
\hline & 298 & $\begin{array}{c}16.18 \pm \\
1.32\end{array}$ & $\begin{array}{c}0.4429 \pm \\
0.0241\end{array}$ & 0.9861 & $\begin{array}{c}100.35 \pm \\
0.95\end{array}$ & $\begin{array}{c}0.0590 \pm \\
0.0122\end{array}$ & 0.9540 \\
\hline & 308 & $\begin{array}{c}16.22 \pm \\
1.34\end{array}$ & $\begin{array}{c}0.4598 \pm \\
0.0247\end{array}$ & 0.9865 & $\begin{array}{c}103.10 \pm \\
0.94\end{array}$ & $\begin{array}{c}0.0566 \pm \\
0.0105\end{array}$ & 0.9650 \\
\hline \multirow{3}{*}{ APB } & 288 & $\begin{array}{c}20.49 \pm \\
2.45\end{array}$ & $\begin{array}{c}0.3655 \pm \\
0.0353\end{array}$ & 0.9570 & $\begin{array}{c}97.05 \pm \\
1.32\end{array}$ & $\begin{array}{c}0.1031 \pm \\
0.0392\end{array}$ & 0.8202 \\
\hline & 298 & $\begin{array}{c}21.35 \pm \\
2.08\end{array}$ & $\begin{array}{c}0.3696 \pm \\
0.0291\end{array}$ & 0.9714 & $\begin{array}{c}111.94 \pm \\
1.19\end{array}$ & $\begin{array}{c}0.1042 \pm \\
0.0367\end{array}$ & 0.8480 \\
\hline & 308 & $\begin{array}{c}23.40 \pm \\
1.58\end{array}$ & $\begin{array}{c}0.3573 \pm \\
0.0204\end{array}$ & 0.9848 & $\begin{array}{c}114.46 \pm \\
1.47\end{array}$ & $\begin{array}{c}0.1144 \pm \\
0.0376\end{array}$ & 0.8658 \\
\hline \multirow{3}{*}{$\mathrm{BE}$} & 288 & $\begin{array}{c}20.40 \pm \\
1.73 \\
\end{array}$ & $\begin{array}{c}0.2989 \pm \\
0.0195 \\
\end{array}$ & 0.9789 & $\begin{array}{c}91.88 \pm \\
0.62 \\
\end{array}$ & $\begin{array}{c}0.1313 \pm \\
0.0369 \\
\end{array}$ & 0.8660 \\
\hline & 298 & $\begin{array}{c}20.57 \pm \\
1.03\end{array}$ & $\begin{array}{c}0.3011 \pm \\
0.0111\end{array}$ & 0.9932 & $\begin{array}{c}107.96 \pm \\
0.21\end{array}$ & $\begin{array}{c}0.1277 \pm \\
0.0306\end{array}$ & 0.9056 \\
\hline & 308 & $\begin{array}{c}20.79 \pm \\
3.36\end{array}$ & $\begin{array}{c}0.3234 \pm \\
0.0377\end{array}$ & 0.9360 & $\begin{array}{c}109.42 \pm \\
0.13\end{array}$ & $\begin{array}{c}0.1137 \pm \\
0.0351\end{array}$ & 0.8588 \\
\hline
\end{tabular}


The adsorption capacity would continue to increase with the increase of $\mathrm{Cd}(\mathrm{II})$ concentration, while there were some inhomogeneities in adsorption. This was consistent with the results of Moyo et al. (2016). The non-linear index $n$ in the Freundlich model was less than 1, which indicated that the distribution of $\mathrm{Cd}(\mathrm{II})$ adsorption sites on the adsorbents were heterogeneous (Fosso-Kankeu et al. 2017).

The parameter $K_{\mathrm{f}}$ measures the strength of the attraction and attachment of Cd(II) onto the surface of the adsorbents. The high $K_{\mathrm{f}}$ value indicates that the attraction force was strong. Table 4 shows that $K_{\mathrm{f}}$ increased with increasing temperature, indicating that the adsorptive force of the adsorbents increased with increasing temperature. At $298 \mathrm{~K}$, the adsorption forces of the adsorbents were ordered as follows: APB (21.35) > BE (20.57) > PB (16.18). According to the parameter $q_{\mathrm{m}}$ of the Langmuir model in Table 4, the theoretical maximum adsorption capacities $\left(q_{\mathrm{m}}\right)$ for the adsorption of $\mathrm{Cd}(\mathrm{II})$ onto the adsorbents were ordered as follows: $111.9 \mathrm{mg} / \mathrm{g}(\mathrm{APB})>108.0 \mathrm{mg} / \mathrm{g}(\mathrm{BE})>100.4 \mathrm{mg} / \mathrm{g}$ (PB), which was the same order as that of the $K_{\mathrm{f}}$ values. The APB had better adsorptive force or capacity for $\mathrm{Cd}$ (II) mainly because the surface of the APB contained various functional groups from the bentonite or the AP biochar, and these functional groups enhanced the attraction force of the adsorbents. Furthermore, the loading of the BE onto the APB composite adsorbent increased the adsorptive sites and enhanced ion exchange.

\section{Thermodynamic Experiments}

The environmental temperature was one of the main factors affecting adsorption. The experimental data of the Cd(II) adsorption at $288 \mathrm{~K}, 298 \mathrm{~K}$, and $308 \mathrm{~K}$ were analyzed by thermodynamic correlation (Fig. 6). The thermodynamic parameters $K D, \Delta G^{\circ}, \Delta H^{\circ}$, and $\Delta S^{\circ}$ are summarized in Table 5.

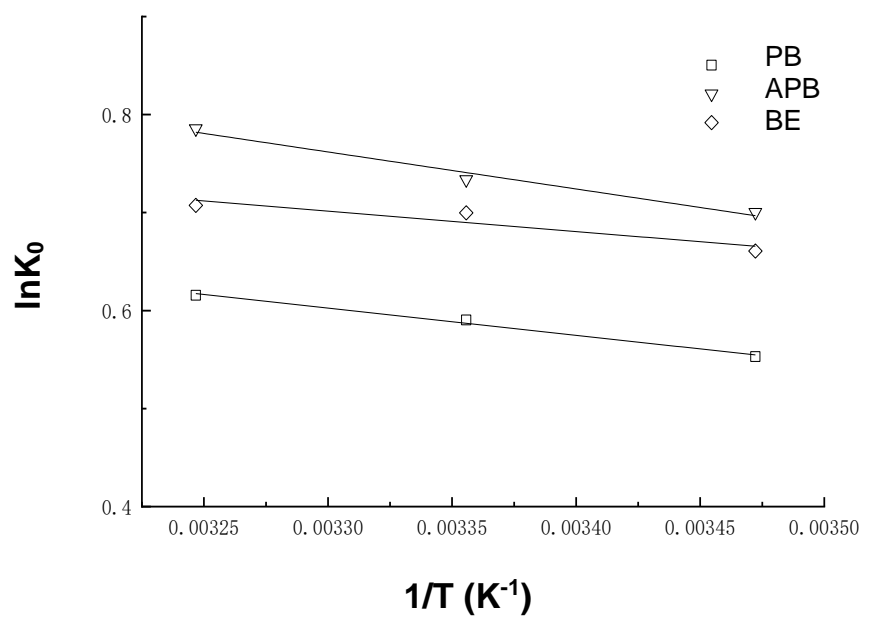

Fig. 6. Effect of temperature on coefficients

The spontaneity of the adsorption process was measured by the standard Gibbs free energy $\left(\Delta G^{\circ}\right)$. The negative value of $\Delta G^{\circ}$ indicates that the adsorption process was spontaneous; the large negative value of $\Delta G^{\circ}$ indicates that the system had high adsorption affinity. Table 5 shows that the values of $\Delta G^{\circ}$ for the different adsorbents were negative at all three temperatures, which indicated that the adsorbents adsorbed Cd(II) spontaneously. 
The values of $\Delta G^{\circ}$ decreased with increasing temperature, which indicated that increased temperature was beneficial to the spontaneous adsorption. Generally, values of $\Delta G^{\circ}$ in the range of $-20 \mathrm{~kJ} / \mathrm{mol}$ to $0 \mathrm{~kJ} / \mathrm{mol}$ indicate that physisorption is the primary adsorption process, while chemisorption is the main adsorption process in the range of $-400 \mathrm{~kJ} / \mathrm{mol}$ to $-80 \mathrm{~kJ} / \mathrm{mol}$ (Yu et al. 2004). In this study, $\Delta \mathrm{G}^{\circ}$ was in the range of $-5.50 \mathrm{~kJ} / \mathrm{mol}$ to -4.07 $\mathrm{kJ} / \mathrm{mol}$, indicating that the adsorption process of $\mathrm{Cd}(\mathrm{II})$ onto the adsorbents was mainly physisorption.

A positive value of $\Delta H^{\circ}$ indicates that an adsorption process is endothermic, and the uptake of adsorbate molecules increases with increasing temperature. A negative value of $\Delta H^{\circ}$ indicates that the process is exothermic, and the increased temperature has an adverse effect on the number of adsorbed molecules. The enthalpy change $\left(\Delta H^{\circ}\right)$ was positive (Table 5), indicating that the adsorption of $\mathrm{Cd}(\mathrm{II})$ by the adsorbents at $288 \mathrm{~K}$ to $308 \mathrm{~K}$ was an endothermic reaction, and the uptake of $\mathrm{Cd}(\mathrm{II})$ onto the adsorbents increased with increasing temperature.

The standard entropy change $\left(\Delta S^{\circ}\right)$ measures the randomness of the adsorption system. A positive value of $\Delta S^{\circ}$ shows increased randomness of the interface between adsorbents and adsorbate molecules (Kara and Tuncel 2011; Fil et al. 2012), while a negative value of $\Delta S^{\circ}$ indicates an increase of orderliness of the adsorption system. With greater order of the system, fewer adsorbate molecules are adsorbed onto the surface of the adsorbents. The values of $\Delta S^{\circ}$ were positive for all systems (Table 5), indicating a decrease in the orderliness of all the adsorption systems. The lowest value of $\Delta S^{\circ}$ was for BE. This might be because the BE was a clay mineral, which had an ordered crystalline layered structure composed of polymeric sheets of tetrahedral $\mathrm{SiO}_{4}$ linked into sheets of octahedral (Al, $\mathrm{Mg}, \mathrm{Fe})(\mathrm{O}, \mathrm{OH})_{6}$ (Ismadji et al. 2015).

Table 5. Thermodynamic Parameters of Cd(II) Sorption

\begin{tabular}{|c|c|c|c|c|c|c|}
\hline \multirow{2}{*}{ Sample } & \multicolumn{3}{|c|}{$\Delta G^{\circ}(\mathrm{kJ} / \mathrm{mol})$} & \multirow{2}{*}{$\Delta H^{\circ}(\mathrm{kJ} / \mathrm{mol})$} & \multirow{2}{*}{$\Delta S^{\circ}(\mathrm{kJ} /(\mathrm{mol} \cdot \mathrm{K}))$} & \multirow{2}{*}{$\mathrm{R}^{2}$} \\
\hline & $288 \mathrm{~K}$ & $298 \mathrm{~K}$ & $308 \mathrm{~K}$ & & & \\
\hline APB & -4.719 & -5.048 & -5.496 & 3.141 & 16.698 & 0.9585 \\
\hline PB & -4.073 & -4.375 & -4.637 & 2.309 & 12.629 & 0.9826 \\
\hline $\mathrm{BE}$ & -4.536 & -4.880 & -5.082 & 1.729 & 11.539 & 0.7628 \\
\hline
\end{tabular}

\section{CONCLUSIONS}

1. A novel clay-biochar composite was prepared by thermal treatment of bentonite (BE) and Alternanthera philoxeroides (AP) at $300{ }^{\circ} \mathrm{C}$ under a nitrogen environment. The SEM and EDS analyses showed that the bentonite-biochar (APB) produced more fragmented substances and had a more developed pore and groove structures than the pristine biochar (PB). The FTIR analysis showed that the stretching vibration absorption peaks of Si-O-Si and Si-O in the APB composites were similar to those in the $\mathrm{BE}$, which indicated that the $\mathrm{BE}$ had been loaded onto the surface of the AP biochar.

2. The pH markedly affected the adsorption of the $\mathrm{Cd}(\mathrm{II})$ by the PB and APB. The adsorptive capacity of the $\mathrm{Cd}(\mathrm{II})$ onto the $\mathrm{PB}$ and APB gradually increased with increasing $\mathrm{pH}$ in the range of 2.0 to 8.0 and reached equilibrium at a $\mathrm{pH}$ of 6.0 . The adsorption kinetic data of the PB and APB fitted the PSO adsorption kinetic model and 
the ID model, which indicated that the time required for the PB to reach equilibrium was less than that for the APB and the second stage of the adsorption process of Cd(II) onto the PB and APB was the rate-controlling step. The rate of the adsorption reaction might have been controlled by surface adsorption, liquid membrane diffusion, and internal diffusion. The Freundlich model fitted the adsorption isotherm data for all the adsorbents better than the Langmuir model, indicating that the adsorption was a multilayer adsorption process involving, and the distribution of the adsorptive sites of $\mathrm{Cd}$ (II) onto the adsorbents was heterogeneous. The thermodynamic study indicated that the adsorption of $\mathrm{Cd}(\mathrm{II})$ onto the adsorbents was mainly physisorption, and the adsorption was an endothermic and spontaneous process, while the orderliness of the adsorption system decreased.

3. The APB showed much higher $\mathrm{Cd}(\mathrm{II})$ adsorption capacity than the PB and BE. In summary, both waste reuse and Cd(II) removal could been achieved by the APB. The APB could be used as an effective and eco-friendly adsorbent to enhance the removal of $\mathrm{Cd}(\mathrm{II})$ from aqueous solution, and it can also provide a theoretical basis for applications in heavy metal pollution remediation from other media.

\section{ACKNOWLEDGMENTS}

This research was supported by the Natural Science Foundation of Shandong Province (No. ZR2013DM005) and the Humanities and Social Science General Project of the Ministry of Education (No. 15YJAZH027). The authors extend sincere gratitude to Yongqiang Cao for help in setting up and running the experiments.

\section{REFERENCES CITED}

Ahmad, M., Rajapaksha, A. U., Lim, J. E., Zhang, M., Bolan, N., Mohan, D., Vithanage, M., Lee, S. S., and Ok, Y. S. (2014). "Biochar as a sorbent for contaminant management in soil and water: A review," Chemosphere 99, 19-33. DOI: 10.1016/j.chemosphere.2013.10.071

Alabarse, F. G., Conceição, R. V., Balzaretti, N. M., Schenato, F., and Xavier, A. M. (2011). "In-situ FTIR analyses of bentonite under high-pressure," Applied Clay Science 51(1-2), 202-208. DOI: 10.1016/j.clay.2010.11.017

Bazrafshan, A. A., Hajati, S., and Ghaedi, M. (2015). "Synthesis of regenerable $\mathrm{Zn}(\mathrm{OH})_{2}$ nanoparticle-loaded activated carbon for the ultrasound-assisted removal of malachite green: Optimization, isotherm and kinetics," RSC Adv. 5(96), 79119-79128. DOI: 1010.1016/j.chemosphere.2013.10.071.1039/C5RA11742A

Cao, Y., Jing, Y., Hao, H., and Wang, X. (2019). "Changes in the physicochemical characteristics of peanut straw biochar after freeze-thaw and dry-wet aging treatments of the biomass," BioResources 14(2), 4329-4343. DOI: 10.15376/biores.14.2.43294343

Chang, P.-H., Jiang, W.-T., Li, Z., Kuo, C.-Y., Wu, Q., Jean, J.-S., and Lv, G. (2016). "Interaction of ciprofloxacin and probe compounds with palygorskite PFl-1," J. Hazard. Mater. 303, 55-63. DOI: 10.1016/j.jhazmat.2015.10.012 
Chen, Y. G., Ye, W. M., Yang, X. M., Deng, F. Y., and He, Y. (2011). "Effect of contact time, $\mathrm{pH}$, and ionic strength on $\mathrm{Cd}$ (II) adsorption from aqueous solution onto bentonite from Gaomiaozi, China," Environmental Earth Sciences 64(2), 329-336. DOI: $10.1007 / \mathrm{s} 12665-010-0850-6$

Fil, B. A., Boncukcuoglu, R., Yilmaz, A. E., and Bayar, S. (2012). "Adsorption kinetics and isotherms for the removal of zinc ions from aqueous solutions by an ionexchange resin," J. Chem. Soc. Pakistan 34(4), 841-848.

Fosso-Kankeu, E., Waanders, F. B., and Steyn, F. W. (2017). "Removal of Cr(VI) and Zn (II) from an aqueous solution using an organic-inorganic composite of bentonitebiochar-hematite," Desalin. Water Treat. 59, 144-153. DOI: 10.5004/dwt.2016.0059

National information and document Standardization Technical Committee. (1996). "Integrated wastewater discharge standard (GB 8978-1996)," China Standards Press. Beijing.

Gupta, V. K., Carrott, P. J. M., Ribeiro Carrott, M. M. L., and Suhas. (2009). "Low-cost adsorbents: Growing approach to wastewater treatment-A review," Crit. Rev. Env. Sci. Tech. 39(10), 783-842. DOI: 10.1080/10643380801977610

Hao, H., Jing, Y.-D., Ju, W.-L., Shen, L., and Cao, Y.-Q. (2017). "Different types of biochar: Effect of aging on the $\mathrm{Cu}(\mathrm{II})$ adsorption behavior," Desalin. Water Treat. 95, 227-233. DOI: $10.5004 / d w t .2017 .21524$

Hayat, M. T., Nauman, M., Nazir, N., Ali, S., and Bangash, N. (2019). "Environmental hazards of cadmium: Past, present, and future," in: Cadmium Toxicity and Tolerance in Plants: From Physiology to Remediation, M. Hasanuzzaman, M. N. V. Prasad, and M. Fujita (eds.), Academic Press, London, UK. DOI: 10.1016/B978-0-12-8148648.00007-3

Holm, L. G., Plucknett, D. L., Pancho, J. V., and Herberger, J. P. (1977). The World's Worst Weeds. Distribution and Biology, University Press of Hawaii, Honolulu, HI, USA.

Huang, X., Liu, Y., Liu, S., Li, Z., Tan, X., Ding, Y., Zeng, G., Xu, Y., Zeng, W., and Zheng, B. (2016). "Removal of metformin hydrochloride by Alternanthera philoxeroides biomass derived porous carbon materials treated with hydrogen peroxide," RSC Adv. 6(83), 79275-79284. DOI:10.1039/C6RA08365J

Hubbe, M. A., Azizian, S., and Douven, S. (2019). "Implications of apparent pseudosecond-order adsorption kinetics onto cellulosic materials. A review," BioResources 14(3), 7582-7626.

Ismadji, S., Soetaredjo, F. E., and Ayucitra, A. (2015). Clay Materials for Environmental Remediation, Springer, Cham, Switzerland. DOI: 10.1007/978-3-319-16712-1

Kara, A., and Tuncel, A. (2011). "Kinetics, isotherms and thermodynamics of the adsorption of lead(II) ions onto porous mono-sized microspheres possessing imidazole functional groups," Adsorpt. Sci. Technol. 29(3), 259-275. DOI: 10.1260/0263-6174.29.3.259

Khan, A. A., and Singh, R. P. (1987). "Adsorption thermodynamics of carbofuran on Sn (IV) arsenosilicate in $\mathrm{H}^{+}, \mathrm{Na}^{+}$and $\mathrm{Ca}^{2+}$ forms," Colloid. Surface. 24(1), 33-42. DOI: 10.1016/0166-6622(87)80259-7

Khan, S., Rehman, S., Khan, A. Z., Khan, M. A., and Shah, M. T. (2010). "Soil and vegetables enrichment with heavy metals from geological sources in Gilgit, northern Pakistan," Ecotox. Environ. Safe. 73(7), 1820-1827. DOI:

10.1016/j.ecoenv.2010.08.016 
Laysandra, L., Santosa, F. H., Austen, V., Soetaredjo, F. E., Foe, K., Putro, J. N., Ju, Y.H., and Ismadji, S. (2018). "Rarasaponin-bentonite-activated biochar from durian shells composite for removal of crystal violet and $\mathrm{Cr}(\mathrm{VI})$ from aqueous solution," Environ. Sci. Pollut. R. 25(30), 30680-30695. DOI: 10.1007/s11356-018-3104-X

Lee, Y., Park, J., Ryu, C., Gang, K. S., Yang, W., Park, Y.-K., Jung, J., and Hyun, S. (2013). "Comparison of biochar properties from biomass residues produced by slow pyrolysis at $500{ }^{\circ} \mathrm{C}$," Bioresource Technol. 148, 196-201. DOI: 10.1016/j.biortech.2013.08.135

Li, X., and Liu, S. (2002). "The harm and prevention and cure of inuasiue of organsiue," Songliao Journal (Natural Science Edition) 4, 96-97

Li, Y., Wang, Z., Xie, X., Zhu, J., Li, R., and Qin, T. (2017). "Removal of norfloxacin from aqueous solution by clay-biochar composite prepared from potato stem and natural attapulgite," Colloid. Surface. A 514, 126-136. DOI: 10.1016/j.colsurfa.2016.11.064

Luo, P., Zhang, H., Wu, Y., Xu, J., and Tian, Y. (2014). "Preparation of bentonite granule and its adsorption to Cr(VI) in water," Non-Metallic Mines 37(2), 72-74, 78.

Ma, Z., Li, Q., Yue, Q., Gao, B., Li, W., Xu, X., and Zhong, Q. (2011). “Adsorption removal of ammonium and phosphate from water by fertilizer controlled release agent prepared from wheat straw," Chem. Eng. J. 171(3), 1209-1217. DOI: 10.1016/j.cej.2011.05.027

Moyo, M., Lindiwe, S. T., Sebata, E., Nyamunda, B. C., and Guyo, U. (2016). "Equilibrium, kinetic, and thermodynamic studies on biosorption of $\mathrm{Cd}(\mathrm{II})$ from aqueous solution by biochar," Res. Chem. Intermediat. 42(2), 1349-1362. DOI: $10.1007 / \mathrm{s} 11164-015-2089-\mathrm{z}$

Paluszkiewicz, C., Holtzer, M., and Bobrowski, A. (2008). "FTIR analysis of bentonite in moulding sands," Journal of Molecular Structure 880(1-3), 109-114. DOI: 10.1016/j.molstruc.2008.01.028

Plazinski, W., Rudzinski, W., and Plazinska, A. (2009). "Theoretical models of sorption kinetics including a surface reaction mechanism: A review," Adv. Colloid Interfac. 152(1-2), 2-13. DOI: 10.1016/j.cis.2009.07.009

Premarathna, K. S. D., Rajapaksha, A. U., Adassoriya, N., Sarkar, B., Sirimuthu, N. M. S., Cooray, A., Ok, Y. S., and Vithanage, M. (2019). "Clay-biochar composites for sorptive removal of tetracycline antibiotic in aqueous media," J. Environ. Manage. 238, 315-322. DOI: 10.1016/j.jenvman.2019.02.069

Ren, X., Wang, F., Zhang, P., Guo, J., and Sun, H. (2018). "Aging effect of minerals on biochar properties and sorption capacities for atrazine and phenanthrene," Chemosphere 206, 51-58. DOI: 10.1016/j.chemosphere.2018.04.125

Rivera-Utrilla, J., Gómez-Pacheco, C. V., Sánchez-Polo, M., López-Peñalver, J. J., and Ocampo-Pérez, R. (2013). "Tetracycline removal from water by adsorption/ bioadsorption on activated carbons and sludge-derived adsorbents," J. Environ. Manage. 131, 16-24. DOI: 10.1016/j.jenvman.2013.09.024

Ünlü, C. H., Günister, E., and Atıc1, O. (2012). "Effect of acidity on xylanmontmorillonite bionanocomposites," Mater. Chem. Phys. 136(2-3), 653-660. DOI: 10.1016/j.matchemphys.2012.07.038

Wang, X., Jing, Y., Cao, Y., Xu, S., and Chen, L. (2019). Effect of chemical aging of Alternanthera philoxeroides-derived biochar on the adsorption of $\mathrm{Pb}$ (II). Water Science and Technology, 80(2), 329-338. DOI: 10.2166/wst.2019.276 
Wang, E.-W., Lei, S.-M., Zhang, S.-C., and Huang, T. (2015a). "Purification of the wastewater of quartz processing by mineral-based porous granulation material," Environm. Sci. 36(3), 969-979. DOI: 10.13227/j.hjkx.2015.03.028

Wang, R., Zhao, L., Shen, Y., Meng, H., and Yang, H. (2015b). Research progress on preparing biochar and its effect on soil physio-chemical properties. Journal of Agricultural Science and Technology (Beijing), 17(2), 126-133. DOI: 10.13304/j.nykjdb.2014.624

Xiao, L., Yang, L., Zhang, Y., Gu, Y., Jiang, L., and Qin, B. (2009). "Solid state fermentation of aquatic macrophytes for crude protein extraction," Ecol. Eng. 35(11), 1668-1676. DOI: 10.1016/j.ecoleng.2008.08.004

Xu, Y.-P., Xie, Z.-B., Zhu, J.-G., Liu, G., and Liu, Q. (2013). "Effects of pyrolysis temperature on physical and chemical properties of corn biochar and wheat biochar," Soils 45(1), 73-78.

Yang, Y., Wei, Z., Zhang, X., Chen, X., Yue, D., Yin, Q., Xiao, L., and Yang, L. (2014). "Biochar from Alternanthera philoxeroides could remove $\mathrm{Pb}$ (II) efficiently," Bioresource Technol. 171, 227-232. DOI: 10.1016/j.biortech.2014.08.015

Yao, Y., Gao, B., Fang, J., Zhang, M., Chen, H., Zhou, Y., Creamer, A. E., Sun, Y., and Yang, L. (2014). "Characterization and environmental applications of clay-biochar composites," Chem. Eng. J. 242, 136-143. DOI: 10.1016/j.cej.2013.12.062

Yu, Y., Zhuang, Y.-Y., Wang, Z.-H., and Qiu, M.-Q. (2004). "Adsorption of watersoluble dyes onto modified resin," Chemosphere 54(3), 425-430. DOI: 10.1016/S0045-6535(03)00654-4

Yu, J., Zhang, X., Wang, D., and Li, P. (2018). “Adsorption of methyl orange dye onto biochar adsorbent prepared from chicken manure," Water Science and Technology 77(5), 1303-1312. DOI: 10.2166/wst.2018.003

Zhao, L., Cao, X., Mašek, O., and Zimmerman, A. (2013). "Heterogeneity of biochar properties as a function of feedstock sources and production temperatures," Journal of Hazardous Materials 256, 1-9. DOI: 10.1016/j.jhazmat.2013.04.015

Zhang, G., Zhang, Q., Sun, K., Liu, X., Zheng, W., and Zhao, Y. (2011). "Sorption of simazine to corn straw biochars prepared at different pyrolytic temperatures," Environmental Pollution 159(10), 2594-2601. DOI: 10.1016/j.envpol.2011.06.012

Article submitted: August 3, 2019; Peer review completed: November 3, 2019; Revised version received: November 30, 2019; Accepted: December 1, 2019; Published:

December 4, 2019.

DOI: 10.15376/biores.15.1.598-615 